\title{
INTEGRASI MEDIA SOSIAL DALAM PEMBELAJARAN GENERASI Z
}

\author{
Awal Kurnia Putra Nasution \\ STAIN Gajah Putih, Aceh Tengah \\ Jl. Aman Dimot No.10, Takengon, Kabupaten Aceh Tengah, Aceh \\ Corresponding Author: awalkpn@gmail.com
}

\begin{abstract}
ABSTRAK
Kemajuan teknologi informasi saat ini sudah merambah semua sektor di dunia pendidikan, tak terkecuali pengajar dan siswa. Siswa yang saat ini merupakan generasi z sangat aktif dalam menggunakan media sosial, dari fakta tersebut penulis merasa perlu untuk mengintegrasikan media sosial ke dalam pembelajaran generasi z. Tujuan penulisan artikel ini untuk mengetahui: (1) media sosial yang dapat diintegrasikan kedalam pembelajaran generasi z; dan (2) cara mengintegrasikan media sosial kedalam pembelajaran generasi $\mathrm{z}$. Metodologi penelitian yang digunakan yaitu kajian pustaka (library research). Media sosial yang bisa diintegrasikan kedalam pembelajaran generasi z yaitu facebook, whatsapp, twitter, dan instagram. Pemilihan ini didasarkan pada populernya aplikasi media sosial dikalangan generasi $\mathrm{z}$, dan semua generasi $\mathrm{z}$ menggunakannya. Adapun cara mengintegrasikan media sosial kedalam pembelajaran generasi $z$, yaitu dengan cara memanfaatkan media sosial facebook, whatsapp, twitter, dan instagram sebagai media pembelajaran. Pada prakteknya media sosial ini dapat digunakan sebagai virtual class, wadah diskusi, wadah berbagi bahan pelajaran, berbagi video dan gambar, serta berbagi link informasi seputar pelajaran.
\end{abstract}

Kata kunci: Media Sosial, Pembelajaran, Generasi z

\begin{abstract}
Advances in information technology have now penetrated all sectors in the world of education, including teachers and students. Students who are currently the Generation Z are very active in using social media, from the fact the writer feels the need to integrate social media into Generation Z learning. The purpose of writing this article is to find out: (1) social media that can be integrated into z generation learning; and (2) how to integrate social media into generation $z$ learning. The research methodology used is library research. Social media that can be integrated into Generation Z learning, namely Facebook, WhatsApp, Twitter and Instagram. This election is based on the popularity of social media applications among the $Z$ generation, and all $Z$ generations use it. The way to integrate social media into Generation $Z$ learning is by utilizing social media Facebook, WhatsApp, Twitter and Instagram as learning media. In practice this social media can be used as a virtual class, a forum for discussion, a place to share learning materials, share videos and pictures, and share information links around the lesson.
\end{abstract}

Keywords: Sosial Media, Learning, Generation z

JTIP@Attribution-ShareAlike 4.0 International License

\section{PENDAHULUAN}

Kemajuan teknologi informasi sekarang ini benar-benar telah melampaui bayangan teknologi informasi dibandingkan dengan 10 tahun yang lalu, saat ini teknologi informasi sudah menjalar di semua lapisan masyarakat, mulai dari kaum muda, kaum tua, bahkan anak-anak. Untuk mengakses teknologi informasi ini, diperlukan perangkat teknologi, perangkat yang umum digunakan adalah smartphone, penggunaan smartphone ini sungguh luar biasa, bahkan anak-anak zaman sekarang mampu menggunakan smartphone di usia yang relative muda, yaitu pada usia 5 tahun.

Generasi saat ini dibagi menjadi beberapa bagian, yaitu generasi $X$, generasi $Y$, dan generasi $Z$. Generasi Z merupakan generasi yang saat ini berada pada usia sekolah, baik itu pada tingkat SMP dan Tingkat SMA, bahkan generasi $\mathrm{Z}$ ini saat ini sudah mulai masuk di bangku kuliah. Generasi Z menggunakan smartphone dalam kesehariannya, 
pemanfaatannya beraneka ragam kebutuhan, dimulai dari sekedar mencari-cari informasi, jualbeli online, sampai salah satu yang tidak bisa lepas dari generasi ini, yaitu akses media sosial. Media sosial yang diakses oleh generasi ini beranekaragam, pada umumnya, whatsapp, instagram, twitter, facebook, dan lain-lain.

Intensitas penggunaan dan pemanfaatan smartphone dalam mengakses berbagai hal pada generasi $\mathrm{z}$ ini secara langsung juga akan mempengaruhi kebiasaan sehari-harinya. Generasi ini terbiasa untuk memanfaatkan kemajuan teknologi dalam memulai semua hal. Pengaruh yang pasti berdampak banyak pada generasi $\mathrm{z}$ pastilah pada sisi pembelajarannya. Generasi ini memang terlahir dalam era kemajuan teknologi, sangat mahir dalam memanfaatkan teknologi dalam mengakses informasi dan menggunakannya sebagai bahan belajar. Generasi $\mathrm{z}$ terbiasa mencari informasi dengan memanfaatkan mesin pencari google dalam kesehariannya [1]. Bahkan generasi ini mengakses media sosial dan memanfaatkannya dalam memperoleh bahan pelajaran. Hal ini juga didukung fakta bahwa media sosial saat ini juga sudah terdapat banyak konten-konten pendidikan.

Berdasarkan fakta bahwa generasi $\mathrm{z}$ yang sangat instens dalam menggunakan media sosial [2] dan pemanfaatan teknologi informasi inilah kemudian penulis merasa perlu untuk membuat artikel yang akan memberi gambaran bagaimana cara mengintegrasikan media sosial ke dalam pembelajaran generasi Z. Seperti kita ketahui bahwa pendekatan pembelajaran bagi generasi $z$ ini harus disesuaikan dengan kebiasaan-kebiasaan mereka sehingga dalam tujuannya akan menciptakan pembelajaran yang menyenangkan bagi generasi $\mathrm{Z}$. pada akhirnya diharapkan generasi $\mathrm{z}$ dapat menerima pembelajaran dengan baik. Adapun tujuan penulisan artikel ini untuk mengetahui: (1) media sosial yang dapat diintegrasikan kedalam pembelajaran generasi z; dan (2) cara mengintegrasikan media sosial kedalam pembelajaran generasi $z$.

\section{METODE}

Penelitian ini merupakan penelitian kualitatif yang bersifat kajian pustaka (library Reasearch) yang menggunakan buku dan sumber literature yang relevan sebagai sumber utama penelitian [3]. Jenis penelitian yang digunakan merupakan penelitian kualitatif, yaitu penelitian yang menghasilkan informasi berupa catatan dan data deskriptif yang terdapat di dalam teks yang diteliti [4]. Dengan penelitian kualitatif, perlu dilakukan analisis deskriptif. Metode analisis deskriptif akan memberikan gambaran serta keterangan yang secara jelas, objektif, sistematis, analitis dan kritis mengenai integrasi media sosial kedalam pemebalajaran generasi z. Pendekatan kualitatif ini dimulai dengan mengumpulkan data-data yang dibutuhkan, kemudian dilakukan klasifikasi dan deskripsi.

\section{Integrasi}

Berdasarkan KBBI, Kata integrasi diartikan sebagai pembauran hingga menjadi kesatuan yang utuh dan bulat [5]. Adapun makna Integrasi yang akan digunakan pada artikel ini yaitu pembauran media sosial ke dalam pembelajaran generasi $Z$, sehingga pembelajaran dan medis sosial dilakukan secara bersamaan dan menjadi satu kesatuan. Integrasi yang yang diharapkan akan memberikan kontribusi besar terhadap keberhasilan tujuan pembelajaran, baik itu yang dilakukan oleh guru maupun dosen di kelas dan di luar kelas.

\section{Media Sosial}

Media sosial merupakan media yang digunakan untuk bersosialisasi. Media sosial menggunakan teknologi berbasis seluler dan website untuk menciptakan platform yang sangat interaktif untuk memungkinkan orang berkomunikasi, berbagi, berkolaborasi, dan memodifikasi konten yang dibuat [6]. Media sosial akan menciptakan koneksi antar penggunanya, interaksi yang berlangsung dapat berupa tukar informasi, berita, berkeluh kesah, saling sapa, dan banyak hal lainnya.

Saat artikel ini ditulis pada bulan februari tahun 2020, pengguna media sosial di Indonesia sangat banyak dan mengalami peningkatan yang luar biasa dari tahun ke tahun. Data Kementerian Komunikasi dan Informatika (kemenkominfo), bahwa pada tahun 2013 pengguna internet di Indonesia mencapai jumlah 63 juta jiwa, yang menarik dari data tersebut, ternyata 95\% akses internet digunakan untuk mengakses media sosial [7]. Data terbaru pada januari tahun 2019, pengguna media sosial di Indonesia mencapai sebesar 150 juta pengguna, dengan kata lain, jumlah ini sebesar 56\% jumlah penduduk di Indonesia [8]. Di Indonesia sendiri, dari banyak flatform pilihan media sosial, seperti youtube, whatsapp, facebook, instagram, twitter, dan lain-lain. Facebook menjadi media yang paling digemari, diikuti oleh instagram, twitter, dan whatsapp [9].

\section{Pembelajaran}

Menurut undang-undang Sistem Pendidikan Nasional No. 20 Tahun 2003, Pembelajaran didefinisikan sebagai proses interaksi perseta didik 
dengan pendidik dan sumber belajar pada suatu lingkungan belajar [10]. Pembelajaran merupakan proses transfer ilmu pengetahun dari pendidik ke peserta didik dengan memanfaatkan sumbersumber belajar untuk tercapainya tujuan pembelajaran yang ingin dicapai. Dari pengertian ini dapat dipahami bahwa sumber-sumber belajar sangat berpengaruh terhadap tercapainya tujuan pembelajaran, sumber-sumber belajar yang dapat dimanfaatkan untuk pembelajaran pada era saat ini khususnya generasi z ialah Media Sosial.

\section{Generasi Z}

Artikel yang ditulis oleh Csobanca tentang generasi z, generasi z di identifikasi dengan beberapa hal berikut [11]:

1. Generasi yang lahir di era milenial.

2. Generasi ini tidak mengenal dunia tanpa internet.

3. Generasi yang selalu menggunakan internet dan sosial network (jejaring sosial)

4. Generasi yang memiliki Global Connectivity, sangat fleksibel, cerdas, toleran, dan dapat bergaul dengan budaya yang berbeda.

5. Generasi ini menggunakan media sosial sebagai alat komunikasi utama.

6. Merupakan konsumen serta penyedia informasi.

7. Mampu menggunakan gawai dengan sangat baik.

8. Memiliki ribuan kontak online.

9. Generasi $\mathrm{z}$ memiliki kemampuan untuk mengambil keputusan dengan cepat.

10. Tidak dapat dibatasi oleh tempat, generasi $z$ tahu bagaimana memanfaatkan gawai untuk menelusuri informasi-informasi di dunia.

11. Cara belajar dan bermain yang sangat berbeda dengan generasi sebelumnya.

12. Generasi z memiliki "Emotional Incopetency" yang menyebabkan kurang kontrol terhadap emosi atau emosi yang suka meledak-ledak.

Dari banyak identifikasi di atas maka sudah dapat dipastikan bahwa generasi $\mathrm{z}$ belajar dengan cara berbeda, dan dengan pendekatan yang berbeda pula. Generasi ini juga tidak bisa di ajar dengan cara yang sama dengan saat kita mengajar generasi sebelumnya. Pembelajaran generasi z ini sangat unik dan selalu melibatkan "networking".

\section{HASIL DAN PEMBAHASAN}

Mengintegrasikan Media Sosial ke dalam Pembelajaran Generasi Z

Mengintegrasikan media sosial kedalam pembelajaran generasi $\mathrm{z}$ dapat diartikan sebagai penggunaan media sosial pada pembelajaran anak didik yang berada pada usia generasi $z$, media sosial 82 akan dimanfaatkan sebaik-baiknya guna mencapai tujuan pendidikan. Penggunaan media sosial dalam pembelajaran tidak boleh hanya sekedar penggunaan saja, tapi harus mengintegrasikannya juga, dalam artian media sosial harus benar-benar didesain penggunaanya sehingga media sosial dan pembelajaran menjadi satu kesatuan. Pemanfaatan media sosial dalam pembelajaran ini juga harus dilengkapi dengan langkah-langkah pembelajaran yang benar dan telah dipersiapkan dengan baik, agar pembelajaran berjalan sesuai dengan rencana pembelajaran. Media sosial yang akan dibahas pada artikel ini ialah media sosial yang populer di Indonesia dan banyak digunakan oleh generasi Z, yakni : Facebook, Twitter, Instagram, dan Whatsapp [12].

Artikel yang di tulis oleh Cilliers yang berjudul The Challenge of Teaching Generation $Z$, bahwa perubahan teknologi yang luar biasa menentukan realitas kita saat ini, berdampak pada pendekatan kita kepada masyarakat, termasuk dalam hal pendidikan. Ada generasi baru yang disebut generasi z yang lahir pada era kamajuan teknologi, hal ini berdampak besar terhadap lingkungan belajarmengajar dalam struktur universitas saat ini, karena siswa (pembelajar Generasi Z) lebih dilengkapi dengan teknologi, daripada Generasi X (dosen) yang khas, sehingga meningkatkan kompleksitas proses pendidikan yang melibatkan pengajaran, bimbingan, dan pengawasan. Studi ini menyelidiki preferensi siswa Generasi $\mathrm{Z}$ baru, dalam hal penggunaan teknologi dalam sistem pendidikan formal, penelitian ini menyimpulkan dengan sudut pandang kedua kelompok dan menyajikan beberapa solusi untuk menjembatani kesenjangan dan meningkatkan strategi belajar-mengajar [13].

Pada artikel yang sama yang di tulis oleh Cilliers yang berjudul The Challenge of Teaching Generation $Z$, dibahas bagaimana kemungkinan untuk mempertemukan generasi $\mathrm{z}$ (siswa) dan generasi $\mathrm{x}$ (dosen) dalam pembelajaran, sebagai berikut:

1. Pengajar yang mengajar Generasi $Z$ harus siap untuk mengajar menggunakan perangkat lunak, perangkat keras, dan media digital, teknologi, dan sosial. Pengaturan ruang kelas yang kreatif perlu menjadi bagian dari proses pendidikan.

2. Menggunakan internet sebagai alat komunikasi dalam pembelajaran serta membuat desain pembelajaran yang berkelompok sehingga terjadi kerjasama kelompok.

3. Meneliti jejaring sosial dan bagaimana mengintegrasikannya kedalam pembelajaran, serta dampak yang ditimbulkan oleh media sosial tersebut. 
4. Menciptakan kelas virtual dengan memanfaatkan media sosial, dengan tujuan untuk menciptakan kelas yang kreatif dan inovatif.

5. Menggunakan aplikasi dan perangkat lunak pendukung untuk menerapkan perubahan pembelajaran.

6. Berubah dari pendekatan pmbelajaran tradisional ke pembelajaran yang lebih berbasis teknologi.

Dari beberapa hal di atas, dapat diambil sebuah garis lurus, bahwa pembelajaran yang tepat digunakan pada generasi $z$, yaitu berupa pembelajaran yang memanfaatkan teknologi di dalamnya, dalam hal ini teknologi yang memungkinkan dimanfaatkan yaitu teknologi media sosial, karena memang pada kenyataanya media sosial digunakan sehari-hari oleh peserta didik dan pengajar.

\section{Facebook}

Jurnal yang ditulis oleh Nasution, yang berjudul Penggunaan Grup Facebook sebagai Virtual Kelas [14], membahas bagaimana cara menggunakan grup facebook sebagai virtual kelas, Nasution menyebutkan langkah-langkah pembelajaran menggunakan facebook, yaitu:

1. Untuk dapat menggunakan layanan grup facebook, tentunya terlebih dahulu pengajar membuat grup yang nantinya berisikan peserta didik dan pendidik.

2. Mengelola pembelajaran di grup facebook, pada proses ini ada 4 tahapan yang dilakukan,

a. Pengajar membuat postingan materi pembelajaran

b. Peserta didik me like, menanggapi, serta bertanya.

c. Peserta didik saling menjawab dan menanggapi postingan

d. Pengajar/dosen memberikan tanggapan berupa komentar dari diskusi pada postingan, dilanjutkan dengan menonaktifkan kolom komentar serta merekap perkuliahan.

Masih pada artikel yang ditulis oleh Nasution, didapat beberapa fitur yang dapat dimanfaatkan pada facebook, yaitu: grup facebook, postingan, menanggapi, dan like, dalam penggunaan facebook ini juga dilakukan kegiatan diskusi dan tanya jawab tidak ubahnya seperti yang dilakukan di dalam kelas.

Facebook sebagai salah satu media sosial paling banyak diakses oleh generasi $z$, dalam aplikasinya juga menyediakan banyak fitur yang bisa dimanfaatkan dalam pembelajaran, berikut ini beberapa fitur yang bisa dimanfaatkan:

1. Grup facebook yang khusus dibuat sebagai kelas virtual

Grup facebook ini dibuat berguna sebagai wadah diskusi dan wadah komunikasi antara siswa dan siswa serta guru yang didalamnya membahas tentang materi pelajaran. Grup facebook juga dapat dimanfaatkan sebagai tempat mengumpul tugas, mengirimkan pesan untuk semua anggota kelas, apabila dalam pembelajaran guru atau siswa ingin berbagi informasi seputar materi pelajaran.

2. Pemanfaatan Facebook apps

Facebook dalam layanannya juga menyediakan beberapa fitur yang memang diperuntukkan untuk mendukung pembelajaran seperti pada education facebook, fitur ini dapat digunakan untuk membuat komunitas belajar serta menyediakan tool untuk dapat membuat program.

3. Mengikuti berita dan informasi tentang pelajaran Untuk mengerjakan tugas, peserta didik dapat mengikuti berita-berita pendidikan, atau yang berhubungan dengan pelajaran, sehingga informasi-informasi tersebut dapat dimanfaatkan untuk menyelesaikan tugas. Peserta didik juga dapat mengikuti atau bergabung pada grup tertentu yang sesuai dengan topik tugas yang sedang dikerjakan.

4. Menggunakan facebook untuk survei atau jajak pendapat

Pada akhir semester, pengajar pasti ingin merevieu proses pembelajaran yang telah dilaksakan sepanjang semester, untuk kegunaan jajak pendapat, pengajar bisa memanfaatkan facebook. Pada praktiknya seluruh peserta didik dipersilahkan untuk memberikan tanggapan dan kritikan atas pembelajaran.

5. Facebook sebagai media berkirim pesan, berkomunikasi dan berkolaborasi

Facebook sudah menjadi salah satu alat berkirim pesan yang popular saat ini, sehingga fitur ini dapat dimanfaatkan untuk dapat saling berkirim pesan, bahkan sebagai media berkirim dan berbagi tugas.

6. Membagikan multimedia

Pembelajaran saat ini sudah memanfaatkan multimedia pembelajaran, facebook merupakan salah satu media sosial yang dapat digunakan untuk membagikan multimedia pembelajaran kepada seluruh peserta didik. 
Whatsapp

Menurut Bounik dan Deshen, dalam artikel yang berjudul WhatsApp Goes to School: Mobile Instant Messaging between Teachers and Students (2014), membahas tentang penggunaan aplikasi whatsapp antara guru dengan siswa, bahwa guru memanfaatkan whatsapp sebagai alat berkomunikasi dalam proses belajar mengajar [15]. Fitur whatsapp yang dimanfaatkan yaitu grup whatsapp, dalam implementasinya grup whatsapp ini memiliki empat tujuan, berkomunikasi antara guru dan siswa, menata suasana positif dalam pembelajaran, sebagai media diskusi antara guru dan siswa serta antara siswa dengan siswa, dan sebagai media berbagi bahan pembelajaran.

Pada prakteknya penggunaan whatsapp dalam pembelajaran selalu memanfaatkan fitur grup whatsapp yang telah disediakan pada aplikasi, sehingga grup akan digunakan dan dimanfaatkan untuk pembelajaran, sama halnya pada pemanfaatan facebook untuk pembelajaran, whatsapp juga dapat digunakan untuk membuat virtual kelas. Beberapa hal yang dapat dilakukan dengan whatsapp dalam pembelajaran, yaitu:

1. Kolaborasi atau kerja sama dalam pengerjaan tugas

Tugas yang diberikan oleh guru pada siswa, sering berupa tugas kelompok, sehingga beberapa siswa harus berkumpul untuk mengerjakan tugas tersebut. Fitur grup whatsapp dalam dimanfaatkan untuk mengerjakan tugas kelompok tanpa harus berkumpul, dalam banyak masalah pengerjaan tugas kelompok adalah keterbatasan waktu anggota kelompok untuk berkumpul disuatu tempat. Pada kenyataannya saat ini semua siswa sudah terbiasa menggunakan grup-grup whatsapp dalam keseharian, sehingga tidak ada salahnya untuk menggunakannya dalam pengerjaan tugas kelompok, diskusi tugas dalam grup whatsapp juga memberikan siswa banyak keleluasaan dalam mengemukakan ide yang ada dalam pikirannya.

2. Memperpanjang waktu belajar

Belajar di sekolah dan di dalam kelas sudah pasti dibatasi oleh waktu, ada saatnya dalam pembelajaran di kelas materi yang disampaikan belum seluruhnya selesai, sementara waktu sudah habis, grup whatsapp adalah solusi dari kurangnya waktu belajar tatap muka, sehingga guru masih dapat menyampaikan hal-hal terkait dalam pembelajaran di grup whatsapp. Mata pelajaran yang memerlukan praktek biasanya juga kekurangan waktu banyak dalam pembelajarannya, mulai dari penyampaian materi sampai proses penilaian, whatsapp dapat digunakan dalam proses penilaian, misalnya dengan memberikan tugas pada siswa dan membuat videonya yang nantinya video tersebut dikumpul lewat grup whatsapp.

3. Mengelola kelas besar

Terkadang dalam mengajar, ada saatnya dilakukan dengan peserta didik yang sangat banyak melebihi 40 orang, saat seperti ini biasanya pembelajaran akan berjalan dengan kurang efektif. Whatsapp adalah solusi yang dapat digunakan saat menghadapi situasi seperti ini, materi pembelajaran dapat dibagikan didalam grup serta wadah pengumpulan tugas-tugas yang diberikan, tanpa harus mengumpulkannya dalam bentuk printout.

4. Berbagi bahan belajar

Whatsapp dapat digunakan untuk berbagi bahan pelajaran, bahan pelajaran bisa saja berupa link tautan, video pembelajaran baik dari youtube dan video buatan sendiri, berbagi gambar materi, berkas dalam bentuk pdf, word, serta informasi-informasi seputar pembelajaran. Whatsapp juga menawarkan diskusi yang dapat dilakukan bahkan dimalam hari.

5. Membangun kepercayaan diri

Dalam proses belajar-mengajar, pasti selalu ada siswa pemalu, whatsapp merupakan solusi dari masalah ini, biasanya siswa pemalu akan mampu mengeluarkan kemampuan terbaiknya dalam mengungkapkan pendapat di dalam grup whatsapp.

Beberapa hal diatas, merupakan hal-hal yang dapat dilakukan dengan aplikasi whatssap yang telah digunakan oleh hampir semua siswa dan pendidik.

\section{Twitter}

Artikel yang ditulis oleh Forgie yang berjudul Twelve tips for using Twitter as a learning tool in medical education, membahas bagaimana menggunakan twitter sebagai alat bantu belajar [16] Dalam artikel ini dikemukankan 12 tips menggunakan twitter dalam pembelajaran. Berikut langkah-langkah yang dimaksud:

1. Membuat akun twitter, hal ini adalah langkah awal pemanfaatan twitter, karena untuk bisa menggunakan twitter, pengguna diwajibkan memiliki akun.

2. Belajar penggunaan bahasa, twitter membatasi penggunaan kata-kata dalam postingan yaitu sebanyak 160 karakter, sehingga untuk benarbenar memanfaatkan twitter dalam 
menyampaikan pesan pembelajaran, harus dilakukan pemilihan bahasa dan kata-kata tepat. Hal ini untuk menjaga tetap tersampaikan pesan yang ingin disampaikan.

3. Membuat akun twitter khusus, twitter khusus yang dibuat diperuntukkan khusus untuk kelas belajar, sehingga ada privasi tertentu, akun ini juga hanya akan membahas seputar pembelajaran saja.

4. Menampilkan diskusi twitter, diskusi di twitter akan dimanfaatkan dalam pembelajaran, hal ini dilakukan untuk meningkatkan partisipasi siswa dalam pembelajaran, siswa juga didorong untuk membuat komentar dan tanggapan atas materi yang disampaikan, bahkan lebih baik lagi kalau siswa membagikan materi tambahan.

5. Menggunakan twitter sebagai sumber belajar yang dipercaya siswa, sudah menjadi hal yang biasa, di internet banyak sekali sumber belajar yang belum terverifikasi kebenarannya, bahkan banyak tulisan yang salah, dengan memanfaatkan twitter sebagai sumber belajar oleh pendidik, maka siswa akan mendapatkan informasi yang jelas kebenarannya.

6. Mengembangkan kemampuan berpikir kreatif siswa, twitter sebagai sarana komunikasi pendidikan akan membutuhkan gaya bahasa yang menarik dan unik, sehingga siswa mautidak mau akan menggunakan bahasa yang menarik di kolom komentar.

7. Menggunakan twitter sebagai media refleksi pembelajaran, siswa saat menggunakan twitter akan lebih leluasa memberikan kritik dan saran terhadap pembelajaran, hal ini dikarenakan rasa segan untuk mengemukakan kritik dan saran saat tatap muka langsung.

Berdasarkan beberapa hal yang telah dikemukakan diatas, maka dari aspek banyaknya hal yang dapat dilakukan dengan menggunakan aplikasi twitter dalam pembelajaran, maka ada baiknya pengajar memanfaatkan twitter juga dalam proses belajar-mengajar.

\section{Instagram}

Perkembangan penggunaan aplikasi instagram saat ini sungguh luar biasa, instagram saat ini sudah merambah banyak sudut kehidupan masyarakat, instagram tidak hanya sekedar media sosial, tempat pencarian informasi dan berita bahkan sudah menjadi lahan pekerjaan bagi sebagian orang. Banyak siswa yang memanfaatkan instagram untuk hal diatas, bahkan salah satu rujukan untuk mode, trend, sampai gaya dalam kehidupan sehari-hari. Bahkan ada istilah, hidup ini harus instagramable. Berdasarkan hal-hal diatas, maka perlulah untuk memanfaatkan instagram tidak hanya sekedar lifestyle, tapi harus didorong lebih jauh dari itu, yakni pemanfaatannya dalam pendidikan.

Artikel yang ditulis oleh Khalitova dan Gimaletdinova yang berjudul Mobile Technologies In Teaching English As A Foreign Language In Higher Education: A Case Study Of Using Mobile Application Instagram, penelitian ini merupakan studi kasus penggunaan aplikasi sosial media dalam pembelajaran bahasa inggris, salah satu tujuan dari penelitian ini ialah untuk apakah aplikasi sosial media instagram dapat meningkatkan pemahaman mendengarkan siswa [17]. Hasil penelitian menunjukkan bahwa aplikasi mobile Instagram dapat berfungsi sebagai sarana yang efektif untuk belajar EFL oleh siswa tingkat lanjut. Aplikasi seluler media sosial Instagram meningkatkan keterampilan pemahaman mendengarkan siswa, khususnya kemampuan untuk memahami pendapat dan informasi spesifik dalam pidato. Instagram memfasilitasi pemahaman mendengarkan dengan syarat bahwa siswa sepenuhnya berpartisipasi dan terlibat dalam pembelajaran mandiri.

Pemanfaatan instagram dalam pembelajaran dapat menggunakan berbagai cara berikut ini:

1. Membuat status yang berhubungan dengan materi pelajaran, agar lebih menarik status yang dibuat disertai dengan gambar-gambar yang menarik.

2. Mengunggah video-video pembelajaran yang nantinya siswa diimbau untuk menonton dan memberikan komentar.

3. Memanfaatkan instagram sebagai alat untuk mengevaluai pembelajaran yang sudah selesai, hal ini akan memudahkan proses evaluasi karena siswa lebih leuasa untuk berkomentar.

4. Memanfaatkan instagram untuk berbagi link website yang berhubungan dengan penyelesaian tugas yang diberikan.

\section{KESIMPULAN}

Media sosial yang bisa diintegrasikan kedalam pembelajaran generasi z yaitu Facebook, whatsapp, twitter, dan instagram. Hal ini didasarkan pada populernya aplikasi media sosial di kalangan generasi $z$, dan semua generasi z menggunakannya. Adapun cara mengintegrasikan media sosial kedalam pembelajaran generasi z, yaitu dengan cara memanfaatkan media sosial facebook, whatsapp, twitter, dan instagram sebagai media pembelajaran. Pada prakteknya media sosial ini dapat digunakan sebagai virtual class, wadah diskusi, wadah berbagi bahan pelajaran, berbagi video dan gambar, serta berbagi link informasi seputar pelajaran. Untuk 
mengoptimalkan media sosial ini dalam penggunaannya pada proses pembelajaran, ada baiknya untuk menggunakan media sosial ini di luar jam pelajaran, sehingga penggunaan media sosial ini berfungsi sebagai penyempurna proses belajar tatap muka. Untuk mendukung proses agar pembelajaran dengan media sosial ini efektif, sebaiknya membuat komunitas sendiri yang berisikan guru dan siswa.

\section{DAFTAR PUSTAKA}

[1] Lokadata.id, Kebiasaan Gen Z dalam menikmati hiburan, 2018. [Online]. Available: https://lokadata.id/artikel/kebiasaan-gen-zdalam-menikmati-hiburan.

[2] L. P. Supratman, Penggunaan Media Sosial oleh Digital Native, J. ILMU Komun., 2018, doi: $10.24002 /$ jik.v15i1.1243.

[3] S. Hadi, Metodologi Research Jilid IV. Jogjakarta: Andi Offset, 1995.

[4] B. I. Mantra, Filsafat Penelitian \& Metode Penlitian Sosial. Yogyakarta: Pustaka Belajar, 2004.

[5] KBBI Online, Integrasi, Badan Pengembangan dan Pembinaan Bahasa (Pusat Bahasa), 2012. .

[6] A. Power, What is social media?, $B r . J$. Midwifery, 2014, doi: 10.12968/bjom.2014.22.12.896.

[7] Kemenkominfo, Pengguna Internet di Indonesia Mencapai 82 juta Orang, 2016. [Online]. Available: https://kominfo.go.id/content/detail/3980/ke mkominfo-pengguna-internet-di-indonesiacapai-82-juta/0/berita_satker.

[8] Katadata.com, Berapa Pengguna Media Sosial Indonesia? | Databoks, Berapa pengguna media sosial di Indonesia, 2019. [Online]. Available: https://databoks.katadata.co.id/datapublish/2 $019 / 0$.

[9] Kompas.com, Facebook Jadi Medsos Paling Digemari di Indonesia, 2019. [Online]. Available: https://tekno.kompas.com/read/2019/02/05/1 1080097/facebook-jadi-medsos-palingdigemari-di-indonesia? page=all.

[10] Depdiknas, Undang-Undang Republik Indonesia Nomor 20 Tahun 2003 Tentang Sistem Pendidikan Nasional. 2003, p. 4.

[11] Z. E. Csobanka, The Z Generation, Acta
Technol. Dubnicae, 2016, doi: 10.1515/atd2016-0012.

[12] Katadata.co.id, 10 Media Sosial yang Paling Sering Digunakan di Indonesia, 2020. [Online]. Available: https://databoks.katadata.co.id/datapublish/2 020/02/26/10-media-sosial-yang-palingsering-digunakan-di-indonesia.

[13] E. J. Cilliers, THE CHALLENGE OF TEACHING GENERATION Z, PEOPLE Int.J. Soc. Sci., 2017, doi: 10.20319/pijss.2017.31.188198.

[14] A. K. P. Nasution, PENGGUNAAN GRUP FACEBOOK SEBAGAI VIRTUAL CLASS, J. AsSalam, vol. 1, no. 2, pp. 27 37, 2017.

[15] D. Bouhnik and M. Deshen, WhatsApp Goes to School: Mobile Instant Messaging between Teachers and Students, J. Inf. Technol. Educ. Res., 2014, doi: 10.28945/2051.

[16] S. E. Forgie, J. P. Duff, and S. Ross, Twelve tips for using Twitter as a learning tool in medical education, Med. Teach., 2013, doi: 10.3109/0142159X.2012.746448.

[17] L. Khalitova and G. Gimaletdinova, MOBILE TECHNOLOGIES IN TEACHING ENGLISH AS A FOREIGN LANGUAGE IN HIGHER EDUCATION: A CASE STUDY OF USING MOBILE APPLICATION INSTAGRAM, in Proceedings of ICERI2016 Conference 14th-16th November 2016, Seville, Spain, 2016, pp. 6155 6161, doi: 10.21125/iceri.2016.0395. 